Article

\title{
Standardized Drought Indices for Pre-Summer Drought Assessment in Tropical Areas
}

\author{
David Romero $^{1, *(\mathbb{D}}$, Eric Alfaro ${ }^{2}$, Roger Orellana ${ }^{3}$ and Maria-Engracia Hernandez Cerda 4 \\ 1 Escuela Nacional de Estudios Superiores, Unidad Mérida, Universidad Nacional Autónoma de México, \\ Ucu 97357, Mexico \\ 2 Escuela de Física, Centro de Investigaciones Geofísicas y Centro de Investigación en Ciencias del Mar y \\ Limnología, Ciudad Universitaria Rodrigo Facio, Universidad de Costa Rica, \\ San Jose 11501-2060, Costa Rica; erick.alfaro@ucr.ac.cr \\ 3 Centro de Investigación Científica de Yucatán, Merida 97205, Mexico; orellana@cicy.mx \\ 4 Instituto de Geografía, Universidad Nacional Autónoma de México, Mexico City 04510, Mexico; \\ mehc@unam.mx \\ * Correspondence: dromero@enesmerida.unam.mx; Tel.: +52-9992-07-4946
}

Received: 17 September 2020; Accepted: 4 November 2020; Published: 9 November 2020

\begin{abstract}
The main climatic indices used for the determination of pre-summer drought severity were developed for temperate zones with very different climatic conditions from those found in the tropical climate zones, particularly with respect to seasonal rainfall variations. The temporal evolution of pre-summer drought leads the authors to compute the indices for each year over a defined period according to the climatic normals of each meteorological station and to consider the months inside the dry episode differently, according to the law of emptying the water reserves. As a function of this, standardized drought indices are proposed for the evaluation of the pre-summer drought in tropical zone. Two new indices were tested: one developed from precipitation and the other also considering temperature. These indices were validated by correlation with Advanced very-high-resolution radiometer (AVHRR) normalized difference vegetation index (NDVI) time series and used to identify the most severe drought conditions in the Yucatan Peninsula. The comparison between the indices and their temporal variations highlighted the importance of temperature in the most critical events and left indications of the impact of global warming on the phenomenon.
\end{abstract}

Keywords: drought; tropical climate; precipitation; temperature; Meso America

\section{Introduction}

The cost of natural disasters grows continuously worldwide [1] and among these disasters, drought impacts the widest areas [2] as it is exacerbated by overextraction of freshwater aquifers [3] even in areas with a humid tropical climate [4]. Due to the importance of the phenomenon, methods used to measure drought have been sought; several authors have developed indices for this purpose $[5,6]$, such as the Palmer drought severity index (PDSI) [7] and the standardized precipitation index (SPI) $[8,9]$ which are the most commonly used [10-12].

The computation of the PDSI requires, in addition to precipitation data, information regarding evapotranspiration, runoff, and soil moisture [13], which is generally difficult to obtain in Mexico and tropical areas since it implies spatially detailed information of the water and soil characteristics of the areas studied. For this reason, the PDSI is rarely used to measure drought in Mexico. Instead, the calculation of the SPI only requires the precipitation data, which are accessible from national databases such as CliCom (Climate Computing Project), administered by the National Meteorological Service and available at (http://clicom-mex.cicese. $\mathrm{mx} /$ ). The SPI is therefore commonly used and is 
particularly recommended for the study and regionalization of droughts in Mexico [14,15]. Additionally, the extensive use of the SPI is supported by the fact that it allows a relative comparison of "dry" and "wet" periods as anomalies of the habitual conditions that are not analogous with the "dry" and "rainy" seasons generated by the precipitation annual cycle. This property allows it to be used for early warnings in climate prediction. For example, a stake holder could have a special interest in identifying "drought" conditions during September and October, the second peak of the rainy season in the Meso American Dry Corridor [16], so the SPI must be defined according to periods that are relevant to the seasonal drought characteristics of a particular area [17]. This is because a relative dry condition during this wet season could affect the accumulated water that is expected in the reservoirs for human consumption and energy generation, and that is expected to be used during the coming boreal winter months, meaning the dry season. This information could be more useful to decision makers, than identifying drought conditions solely during the dry seasons of the annual cycle, in which no important rains are expected anyway. The SPI allows the evaluation of the drought for a chosen period and depending on the normal conditions. Its equation is given by (1) [8]:

$$
S P I_{i t}=\frac{P_{i t}-\bar{P}_{i}}{S_{p i}}
$$

where $P_{i t}$ is the amount of precipitation measured at point $i$ during period $t, \bar{P}_{i}$ the mean of precipitation at point $i$, and $S_{p i}$ the standard deviation of precipitation at point $i$. This is calculated for defined periods, 3, 6, 12, or 24 months, also called "scale" [18] depending on the study of drought persistence.

However, the SPI and the PDSI were developed for temperate zones (i.e., the U.S. states of Iowa, Kansas, North Dakota, and Colorado) $[7,8]$ which have very different climatic conditions than those found in tropical zones. In tropical regions, rainfall is far more important than temperature variation for estimating drought severity so, the study of the evolution of drought episodes resides in the rainfall regimes: the tropical zones experience a very marked rainfall temporality with months of scarce rainfall and a season of abundant rainfall exceeding the surplus-in one month. On the contrary, in the temperate zones, even the rainy season can have a precipitation deficit with respect to evaporation because for the places cited above, the most rainy season occurs during summer but the amount of rain does not always compensate for the evaporation generated by the increase in temperatures. This is not possible in areas with a hot, humid, and sub-humid type A climate because in these areas with a very marked summer rainy season, the first heavy rainfall stops the pre-summer drought.

The timing of drought is a crucial consideration for crops because sowings dates are timed to coincide with the onset of "normal" rain and later to enable the production of honey, which is dependent on the rains of the dry episode. A standardized index is then ideal for this purpose since it is not necessary to integrate elements such as soil which is an invariable factor for each point. Nevertheless, in areas of climate type A, the calculation of the SPI 12 months used for this same study area [19] or for Mexico in general [20] cannot be a good indicator of the drought since it integrates periods that have different incidences, and it is heavily biased by the summer rains that represent most of the precipitation. In addition, the efficiency of the rain to recharge the water reserves is reduced for events of high intensity of rain. [21].

A climate zones, can present two types of drought: the mid-summer and the pre-summer. The first corresponds to a relatively short period of time (less than two months) with a decrease in rainfall, in the middle of the rainy season, and with high temperatures, called mid-summer drought or MSD; canícula or veranillo in Spanish [22-24]. The vulnerability of the areas to the heat wave depends directly on the duration of the episode and the retention capacity of the soil [25]. The pre-summer drought, on the other hand, has a slow and lasting development process, since it begins during a cooler period, at the end of the rainy season, and exhibits occasional rainfall linked to the cold fronts, called nortes [26], which rarely causes the average winter rainfall to be less than $5 \%$ of the annual total $[27,28]$. 
The objective of this study is to create a drought index that contributes to the characterization of the severity of the pre-summer drought in areas of humid and sub-humid tropical climate; type A according to Köppen classification [29] and its modification by Garcia [30]. Several indices and indicators have been developed because each drought type and climatic zone have particularities that must be considered [31].

\section{Data and Methods}

\subsection{Yucatan Pre-Summer Drougth}

The Yucatan Peninsula, a vast Mexican region with a diversity of tropical climates, mostly hot humid and sub-humid. The climates present are mainly of type $A x^{\prime}(w), A w, A m$ and, in the northern strip is semi-arid and arid type BS [28,32] (Figure 1) where A indicates a tropical megathermal climate. The rainfall regime is used to identify each of the climates of group A: Af, tropical rainforest climate; Am, tropical monsoon climate; Aw, tropical wet and dry climate; and Ax' $(w)$, tropical intermediate climate between Am and Aw with a dry season during winter; this category takes part of Aw in Köppen classification [29]. These climates have considerable precipitation, with an annual rainfall temperature greater than potential evapotranspiration separating them from tropical BS, semi-arid climate.

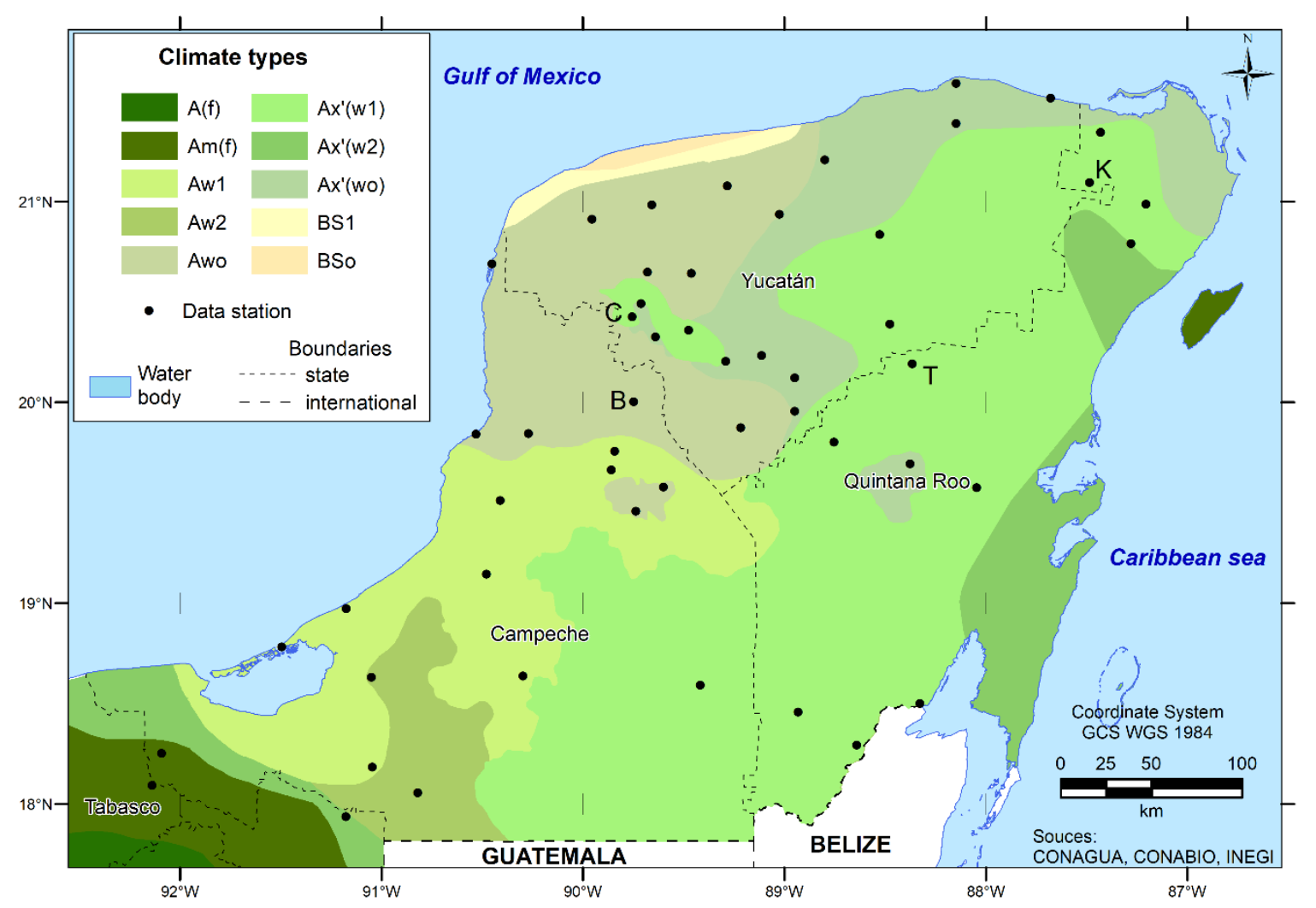

Figure 1. Climate types according with Köppen modified by Garcia system in the study area and location of data stations used (B: Bolonchen, C: CIAPY, T: Tihosuco and K: Kantunilkin).

Strictly, the peninsula does not contain Af climate zone. Every place can be affected by pre-summer drought. According to the climate type, the duration of the episode in the study area varied from 2 (Am) to $8(\mathrm{Aw})$ months with a median of six months (November to April or December to May).

Due to its long duration and its causes, the pre-summer drought can be parcellated into two parts, the "winter" drought, which will depend on the activity of the cold fronts from the end of the rainy season until its usual beginning, and the drought due to the delay of the summer rains. Although there is a temporal continuity between the "winter" drought, which occurs annually, and the eventual delay 
of the summer rains, it is interesting to separate them since they do not have the same impact on the activities or on the local human populations. The first episode impacts on honey production, permanent crops and livestock, implying the need for irrigation [33], as well as the extension of forest fires. As for the second episode, it mainly impacts on the delay of rain-fed agriculture. The study the onset of the rainy season is important because early (late) onsets tend to be associated with wetter (drier) May-June season, the first peak of the rainy season. So, having a late start of the rains, followed by a drier season in May-June in conjunction with a deep MSD in July and August, would affect significantly key socioeconomic sectors like agriculture during the primera period, i.e., the period of the year associated with the spring phase of agricultural activity and its harvest.

\subsection{Data}

The national climate database for Mexico is integrated into the Climate Computing (CliCom) project by the National Meteorological Service of Mexico (SMN). The observations in each of the 5459 observation stations in the country are made daily at 08:00 local time (e.g., 12:00 UTC). The value reported for the daily observation represents the data for the previous $24 \mathrm{~h}$, ending at $08: 00$. The CliCom data series runs from 1902 to 2017, however, the stations have data periods ranging from 30 days to 107 years with a median of 29 years. The data included are daily and monthly values of observed temperature, minimum and maximum $\left({ }^{\circ} \mathrm{C}\right)$, precipitation and evaporation $(\mathrm{mm})$, daily occurrence of thunderstorm, dew, hail, fog, frost, and two levels of cloudiness.

The region has 140 stations of the 5469 that make up the national network. Considering the small number of stations $(<20)$ with data prior to 1952, CliCom stations with at least 40 years of data from 1952 to 2016 were selected for this study. The number of climate stations finally retained for the work was 58 (Figure 1). In this study, we utilized monthly data from the selected stations, including precipitation, maximum and minimum temperature which were processed in $R$ version 4.0 [34].

In order to compare the correspondence of the indices to a remotely sensed index of vegetation cover and condition, we used Advanced very-high-resolution radiometer from the National Oceanic and Atmospheric Administration (NOAA-AVHRR) satellite images obtained from the image bank of the Geospatial Analysis Laboratory of the Institute of Geography of the National Autonomous University of Mexico (UNAM). The period of available images extends from 1996 to 2012. From these images, selected from various platforms and sensors depending on their quality, we calculate the normalized difference vegetation index (NDVI) [35] using methods applied by Granados et al. [36] and with the daily layers obtained, we composed biweekly compounds from 1996 to 2012, with a spatial resolution of $1 \mathrm{~km}$ pixel size. Although the use of data from various satellites is required, reliable large time-series of NDVI can be computed from NOAA-AVHRR images [37].

\subsection{Indices Creation}

In this study we applied three methodological steps in the computation of standardized indices. First, we calculated the standardized indices only for the drought period, which is defined for each location from the ombrothermic diagrams [27,38]; we separated the usual months of the pre-summer drought, for example, in Aw climate, the months before the summer rainy period that have $\mathrm{P}<2 \mathrm{~T}+28$, where $\mathrm{P}$ is the average monthly precipitation $(\mathrm{mm})$ and $\mathrm{T}$ the average monthly temperature $\left({ }^{\circ} \mathrm{C}\right)$. The separation of this period for the evaluation of rainfall anomalies and the determination of drought severity was also developed by other authors [39].

Second, in order to treat the months within the dry episode differently and to consider an evolution akin to the Dupuit-Boussinesq equation, we applied weighting factors which depend on the position of the month in the dry episode, derived from an exponential function. We integrated this function in the index computation because the water present in the soil after precipitation is affected by infiltration and evaporation, so its quantity decreases over time. This circulation of water in the soil and subsoil, which induces the emptying of the reserves, and the slow evolution of the droughts that this entails, demonstrates the need to consider the precipitation at the beginning and end of the drought episode in 
a different way. If the area is considered as a water reserve, it can be inferred that the water decrease and, therefore, the evolution of the drought is relative to the Boussinesq water reserve emptying equation reported by Hall [40] and linearized based on the assumptions postulated by Dupuit [41]. The Dupuit-Boussinesq equation establishes a negative exponential function to describe the emptying of water reserves in general, linked mainly to the water table but also retained by the soil [25] (2):

$$
Q_{t}=Q_{0} e^{-\alpha t}
$$

where $Q$ is the emptying of the reservoir, $t$ is the time and $\alpha$ is the emptying coefficient. The emptying coefficient is a critical property of the soil and is complementary to the water retention characteristics of the soil [42], since it indicates the temporal evolution rather than the vertical evolution. Generally, the recession constant corresponds to a decreasing rate of water flow $[43,44]$.

This was also employed by other authors to calculate the coefficient of previous rainfall [45] or to evaluate the moisture conditions of the reserves [46] from daily rainfall data.

In practice, this means that to evaluate the intensity of a dry episode, which will always have its peak at the end of the period simply because drought is a slow onset phenomenon [47], it is necessary to apply to the rainfall data a variable coefficient depending on the position of the month in the dry episode. (3 and 4 ):

The equation of the pre-summer drought index considering precipitation (ISPP) is given by

$$
\begin{gathered}
P_{i}=\sum_{j=1}^{n} p_{i j}\left(\exp ^{\left(\frac{\dot{j}}{j}\right)-1}\right) \\
\operatorname{ISPP}_{i}=\frac{P_{i}-\bar{P}_{i}}{S_{P i}}
\end{gathered}
$$

where $I S P P_{i}$ is the dry season index (precipitation) at point $i, p_{i j}$ the precipitation of month $j$ at point $i$, $j$ the position of month in the dry season and $n$ the maximum value of $j$, i.e., the duration of the dry season (months). $P_{i}$ is the weighted total precipitation of the season, $\bar{P}_{i}$ is the average total precipitation of the season for the whole data period, $S_{P i}$ is the standard deviation of total precipitation for the whole data period.

Finally, in addition of the ISPP, we developed the ISPB index which has as input data water balances instead of precipitation. The water balance is the subtraction between the area's water inputs (precipitation) and outputs (interception, evaporation, transpiration, infiltration, and runoff) but how it is measured depends on the temporal and spatial scales [48] as well as the purpose. At the scale of an event with the pre-summer drought, which lasts several months, it can be simplified to the relationship between rainfall and evaporation [49] which can be defined as the climate water balance [50], and as insolation varies little in the tropical domain, evapotranspiration is mainly determined by temperature. Therefore, we decided to consider temperature and to include its effect in the assessment of droughts.

We computed the water balance with the equivalent subtraction of the equation of balance between precipitation and evaporation as determined by Garcia [30] in Mexico's climate classification. Thus, the water balance is estimated according to (5):

$$
b_{i j}=p_{i j}-2 t_{i j}-C
$$

where $b_{i j}$ is water balance in point $i$ for month $j, p_{i j}$ its total precipitation, $2 t_{i j}$ its average temperature and $C$, the constant used by Garcia [30] to determine the balance according to the rainfall regime (it can be 14,21 , or 28 ).

Consequently, the pre-summer drought index-water balance equation is given by (6 and 7):

$$
B_{i}=\sum_{j=1}^{n} b_{i j}\left(\exp ^{\left(\frac{j}{j}\right)-1}\right)
$$




$$
I S P B_{i}=\frac{B_{i}-\bar{B}_{i}}{S_{B i}}
$$

where $I S P B_{i}$ is the dry season index (water balance) at point $i, j$ the position of the month in the dry season and $n$ the maximum value of $j$, i.e., the duration of the dry season (months). $B_{i}$ the weighted seasonal water balance, $\bar{B}_{i}$ the average seasonal water balance for the whole data period, $S_{B i}$ the standard deviation of the water balance for the whole data period.

According to Garcia (2004), depending on climate subtype A (f, m, w, or $x$ ), the value to be subtracted in Equation (4) may change. However, since this number is a constant for each monitoring station, the change of the value does not affect the calculation of $I S P B_{i}$.

For both indices, we applied the same index value ranges for the determination of the severity of droughts as those determined by McKee et al. [8].

We calculated SPI 12 months (from May to April), SPI usual drought period (SPI drought), ISPP and ISPB for all the seasons with the objective of comparing the sensitivity to the values of drought and identified the differences in the values of the drought indices in the extreme years, contrasting these data with the annual reports of CENAPRED (acronyms meaning in English National Center for Disaster Prevention) or SAGARPA (acronyms meaning in English Secretariat of Agriculture, Livestock, Rural Development, Fisheries, and Food). Finally, we extracted the trend and the relative $p$-value [51] for the 4 indices time-series in each of the 52 stations using linear regression method.

\subsection{Validation of the Indices}

In this study, we compared the values of the indices calculated for each year with the values of NDVI relative to the place and the season of drought evaluated. The NDVI, which is a method developed to estimate the growth and condition of vegetation with remote sensing [52,53] is recognized as a good indicator of drought $[54,55]$. Although the NDVI gives information about the state of the vegetation, the drought indices determine the severity of the drought by location, which depends on the usual conditions. Temporal variation in NDVI can result from changes in either vegetation condition (e.g., drought stress and phenology) or abundance (e.g., biomass and cover). Consequently, it is not possible to use the NDVI to validate index data from spatial correlations, but only from temporal ones.

We extracted the NDVI time-series for each pixel relating to the location of the weather stations used from the biweekly NDVI compounds, using the ENVI 4.2 program.

Finally, we validated the values of the drought indices obtained thanks to the correlation between the time-series of the indices and the series of the average biweekly NDVI value for April of each year at the pixel to which each compared station belongs.

\section{Results}

\subsection{Application of the Indices}

The time-series of the four calculated indices (Figure 2), shows a strong dispersion of the values which indicates heterogeneous conditions in the Yucatan Peninsula since most of the bars in the graphs reveal a wide range and interquartile interval of the values present for each of the indices tested. This is in accordance with what Gomez Diaz et al. [19] report in their classification of droughts according to their intensity in different regions of the area. There is also a certain cyclicality with clear periods of decrease in the indices from 1959 to 1963 or from 1983 to 1988 and other periods of increase, such as from 2005 to 2008. 


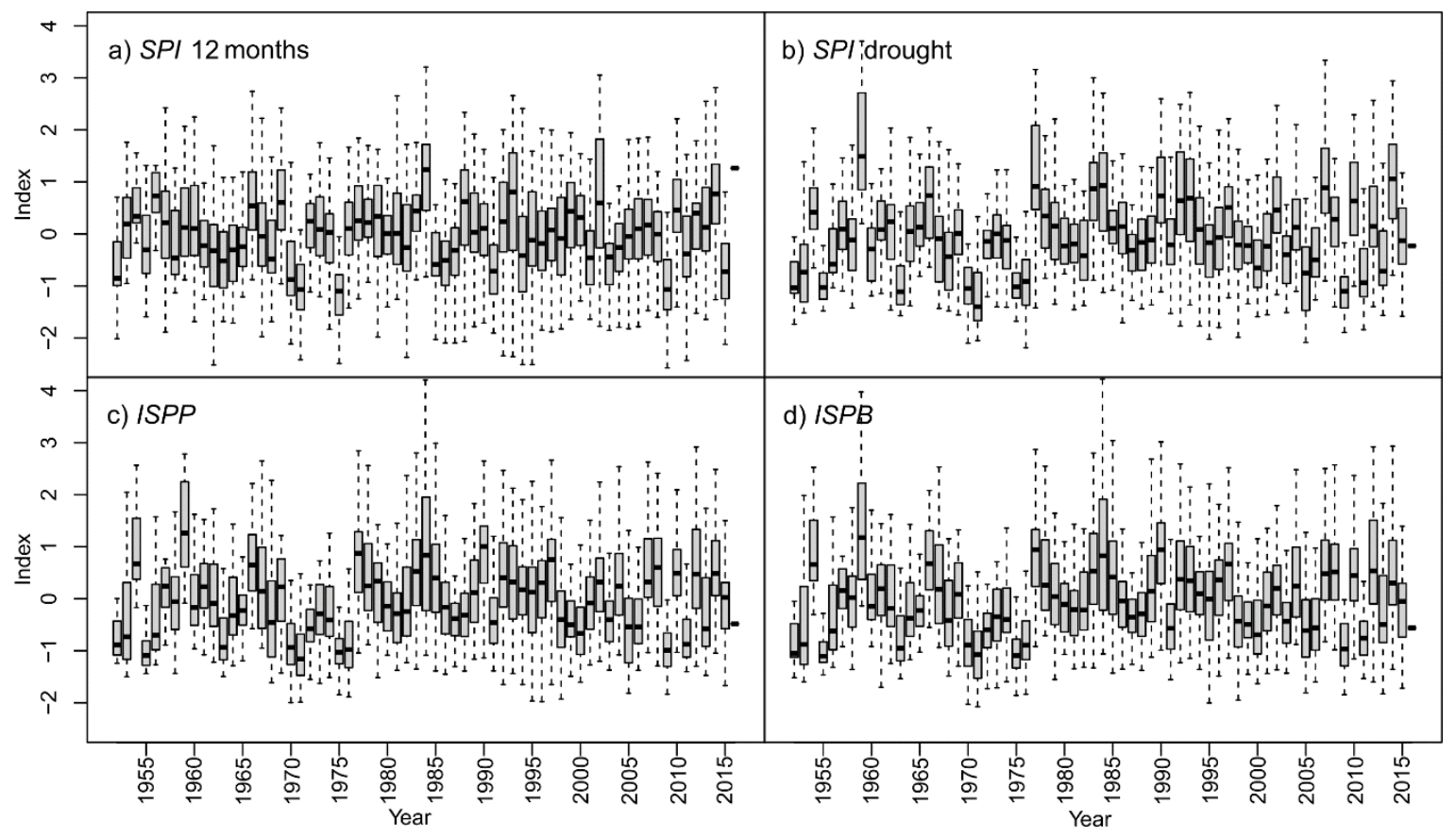

Figure 2. Time-series of Standard Precipitation Index 12 months (a), Standard precipitation Index for pre-summer drought period (b) pre-summer drought index-precipitation (ISPP) (c) and pre-summer drought index-water balance (ISPB) (d) for 52 stations in the Yucatan Peninsula.

We observed few years to have negative indices across the entire peninsula, 1970 for the SPI drought and 1955 and 2009 for both new indices. For the first of these two cases, the SPI drought gives positive values in Quintana Roo state and for the second a slightly positive value in Yucatan state. The droughts that affected all the recording stations used within each one of the three states of the peninsula are reported to know the spatial amplitude of the global phenomena at state or regional level [56], the years 1953, 1956, 1968, 1971, and 1976 were dry for all the indices in Quintana Roo. On the contrary, there are no other years apart from 1955 and 2009 that gave negative maximum values for Campeche state or Yucatan.

\subsection{Identification of Extreme Episodes}

With the ISPP, we detected 621 cases of moderate to extreme droughts during the registration years of the stations studied, while the ISPB showed 626 cases (Table 1). The values indicating extreme drought $(<-2)$ occurred once with ISPP, in Kantunilkin (Figure 1) in 1975 and six times with ISPB (Kantunilkin in 1975 and in other localities of Yucatan and Quintana Roo in 1970, 1971, 1995, 1999, and 2009). However, the number of severe droughts detected was also higher for ISPB, for each year that exhibits extreme or severe situations in some seasons, a large part of the territory also experiences at least moderate drought.

\subsection{Times-Series Trends}

The trend values calculated from the time-series of the four indices tested (Table 2) have similar average data that indicate a decrease in the intensity of the drought due to increased rainfall, mainly in the usual dry season but also indicate heterogeneous situations in the study areas. The coefficients are positive, which suggests that droughts became less frequent or severe over the past decades and could be interpreted as climatic change is predicted to result in less precipitation in arid regions, and as increased rainfall in tropical areas. The observation of the most significant trends, for which $p$-value $<0.1$, reinforces this information since the mean values of the trend coefficients are still higher. 
Table 1. Grand total and years of greatest occurrence of the three highest levels of drought (extreme, severe, and moderate) with the ISPP and ISPB indices (1952-2017).

\begin{tabular}{ccccccc}
\hline \multicolumn{1}{c}{ ISPP } & & \multicolumn{3}{c}{ ISPB } \\
\hline Year & Extreme & Severe & Moderate & Extreme & Severe & Moderate \\
\hline 1955 & 0 & 1 & 20 & 0 & 2 & 18 \\
1963 & 0 & 1 & 21 & 0 & 2 & 18 \\
1971 & 0 & 12 & 27 & 1 & 12 & 23 \\
1970 & 0 & 4 & 24 & 1 & 3 & 22 \\
1975 & 1 & 4 & 27 & 1 & 6 & 29 \\
1976 & 0 & 6 & 17 & 0 & 4 & 18 \\
2005 & 0 & 6 & 20 & 0 & 11 & 14 \\
2009 & 0 & 11 & 25 & 1 & 10 & 20 \\
2011 & 0 & 1 & 29 & 0 & 3 & 28 \\
\hline Total & 1 & 91 & 528 & 6 & 98 & 516 \\
\hline
\end{tabular}

Table 2. Statistical values of the trend coefficients calculated from the time-series (1952-2016) of the four indices (standardized precipitation index (SPI) 12 months, SPI drought, ISPP, and ISPB).

\begin{tabular}{ccccc}
\hline \multirow{2}{*}{ Index } & \multicolumn{4}{c}{ Trend Coefficient } \\
\cline { 2 - 5 } & Average & Minimum & Maximum & Average If $\boldsymbol{p}$-Value < 0.1 \\
\hline SPI 12 & 0.0032 & -0.0238 & 0.0277 & 0.004 \\
months & & -0.017 & 0.0262 & 0.0089 \\
SPI drought & 0.0048 & -0.0156 & 0.0273 & 0.0055 \\
ISPP & 0.0046 & -0.0135 & 0.0304 & 0.0178 \\
ISPB & 0.0045 & &
\end{tabular}

\subsection{Validation of the Indices with NDVI}

The correlation coefficients between the NDVI time-series with each index show a greater relationship for the calculations that extract the usual drought period (Table 3). The average validation values are better for ISPP and ISPB than for SPI drought, but with minimal differences also, the ISPB gave better results on average at the regional scale, but the SPI of pre-summer drought period or the ISPP were able to over perform it in some stations.

Table 3. Correlation coefficients between normalized difference vegetation index (NDVI) data and drought indices (1996-2012).

\begin{tabular}{ccccc}
\hline Location & SPI 12 Months & SPI Drought & ISPP & ISPB \\
\hline Average & 0.071 & 0.388 & 0.424 & 0.426 \\
Bolonchen & 0.302 & 0.699 & 0.71 & 0.727 \\
Tihosuco & 0.065 & 0.549 & 0.669 & 0.664 \\
CIAPY & 0.419 & 0.703 & 0.667 & 0.718 \\
\hline
\end{tabular}

Although the correlation averages are low, a significant difference can be detected between the traditional 12-month SPI and the other indices, evidencing the importance of restricting the computation period to the usual dry months. Furthermore, high correlations were found for the most forested areas of the northern half of the peninsula, where hydromorphy is low and NDVI more dependent on weather conditions than on fluctuations in the underlying water table (i.e., stations of Bolonchen, Tihosuco, and CIAPY) (Figure 1, Table 3).

\section{Discussion}

The standardized drought indices benefited from better validation than the SPI and allowed the detection of the main dry events. The year 2009, which stood out in the series studied for having negative 
ISPP and ISPB indices throughout the Yucatan peninsula, was recorded as the most expensive due to drought damage with 86.3 million Mexican pesos (approximately 6.5 million USD at 2009 exchange rate) and 9666 animal units affected according to Estrada-Medina et al. [57] from official data [58,59]. This is related to the spatial distribution of drought severity (Figure 3). This representative map of the 2009 drought, made with the Thin Plate Spline radial interpolation method [60], despite being calculated with a smoothing method, shows a great spatial variation, as also indicated by other authors [39] since the Yucatan Peninsula is a flat landform tropical region (altitude $<400 \mathrm{~m}$ ) between the Gulf of Mexico and the Caribbean Sea $\left(86^{\circ} 45^{\prime}-92^{\circ} 30^{\prime}\right.$ West and $17^{\circ} 45^{\prime}-21^{\circ} 45^{\prime}$ North) and therefore lacks orographic convection, favoring a high spatial variability of precipitation. The livestock area in the northeast of Yucatan state was most affected by the phenomenon. On the same map, it is notable that, although the drought impacted the entire Yucatan peninsula, it did not affect the entire territory in the same way since it had a low amplitude in the South of the Yucatan state and central Quintana Roo and, on the contrary, it was quite severe in the South of Campeche, an area considered one of the most humid.

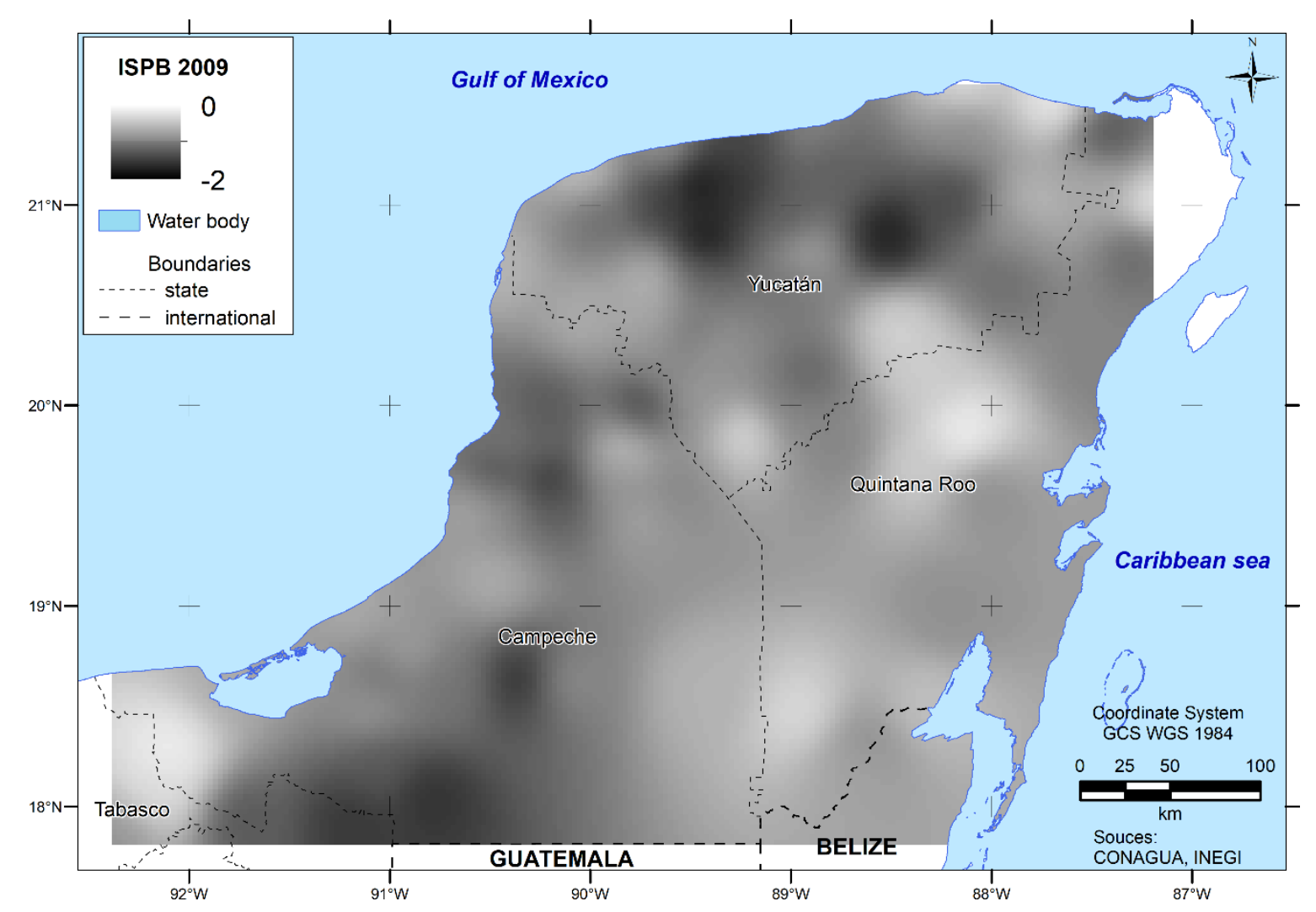

Figure 3. Spatial variation of the 2009 pre-summer drought measured with the ISPB index.

In contrast, no episode of drought detected by these methods corresponds to the extreme events reported by Florescano [61] for Mexico and only 2011 drought correspond also to a national scale report in a historical work with a longer study period for the country as a whole [62]. However, this is consistent since Mexico's predominant weather conditions are not representative of those in the Yucatan Peninsula. The number of droughts at the state level does not correspond with what Florescano found and what Gómez Rojas reported [56] although the study periods are different. We also found several partial droughts that are not considered in these works. Abnormally low rainfall conditions in specific areas were mapped by Garcia and Hernandez [63] using the statistical mode and asymmetric distribution curve. Although this work considers the whole year, some episodes are also reflected, such as the extreme drought in Northern Quintana Roo in 1975.The extreme dry period of 1975 found in this study, was identified previously by Alfaro [64] as an anomalous cool period in the North 
Tropical Atlantic sea surface temperatures, these cool events are associated with drier periods in the intra-American seas (e.g., [65-68]). Two other coincidences with Alfaro [64] are 1971 and 1976.

The ISPP index has the advantage of permitting the evaluation of a drought with precipitation data and emphasizes on the most critical periods within each dry episode. However, this index does not consider the evolution of evapotranspiration, whereas ISPB does. The differences between the temporal trends related to the indices time-series highlight the interest in the application of the ISPP or ISPB which show a modification in the temporality of the pre-summer rains. First, the trend values of the SPI 12 months are more dissimilar with respect to the others, which demonstrates more the unsuitability of the index for the study of the drought in the tropical zones. Second, the trend averages indicate a decrease in the intensity of the drought, but the ISPP, and particularly the ISPB, has lower values than for the SPI. Locally, however, trends are also found for increased pre-summer drought, as demonstrated by Mardero et al. [39] for the southern Yucatan Peninsula, and as predicted by most of the models applied by Orellana et al. [69] in different climate change scenarios for the area.

The differences found, although slight, between SPI drought, ISPP, and ISPB in the calculation of trends, may mean that the increase in rainfall does not affect the months of greatest importance for the drought in general terms. However, they give indications of being affected by global warming by the lower average values for ISPB trend.

The present study is consistent with the conclusions of other authors on drought evaluation in temperate [17] and in tropical domain [70] with marked differences in the annual rainfall cycle. They found differences in the efficiency of the drought indices calculated for various time scales (3, 6, 9, and 12 months) in sub-regions of their study area. Quesada-Hernandez et al. [16] studied the year to year (i.e., interannual) spatial and temporal variability of dry and wet episodes at the Central American Dry Corridor (CADC), which is a sub-region in the isthmus that is relatively drier than the rest of the territory and located mainly in the Central America's Pacific coast. They noticed that using different indices could give very different CADC spatial extensions through the years, so they suggested the previous and proper drought index identification or its adaptation for a particular region, like the ones proposed in this study, when drought impacts are analyzed. This drought index identification or adaptation is crucial for two main reasons. First, the identification of areas that change their classification during extremely dry conditions is important because these areas may indicate the location of future expansion of aridity associated with climate change and second, the delineation of the CADC during wet extremes in Central America allows the identification of locations that remain part of the CADC even during the wettest years and that may require special attention from the authorities.

\section{Conclusions}

The description of droughts accurately enough with only one index is not possible [16]; although, it could be practically useful. The standardized drought indices developed in this study allowed an adequate evaluation of the pre-summer drought phenomenon of each year in the Yucatan Peninsula thanks to the processes of separation of the usually dry period and the integration of factors related to the speed of water decrease, as well as temperature. Particularly, the application of the indices could allow the identification of the most problematic pre-summer drought years in the Yucatan Peninsula [58,59], as well as the multi-year trend of the phenomenon.

A result of interest and great significance for the study of the drought appeared with the frequency of dry events with ISPP and ISPB. ISPB detected six times more extreme droughts and $13 \%$ more severe droughts than ISPP while the total of extreme to moderate droughts varied only by $0.8 \%$. This leads to the confirmation that temperature is a truly aggravating factor in the driest episodes and should be considered in the calculation of the indices so as not to underestimate drought phenomena [71]. Furthermore, the inclusion of the effect of temperature in the evaluation of the drought process, allows the potential impact of "global warming" or "climate change" [72] to be considered and permitted us to indicate an initial change in the regime through the analysis of the trends of the drought indices. 
Author Contributions: Conceptualization, D.R.; methodology, D.R.; software, D.R.; validation, M.-E.H.C.; formal analysis, D.R.; investigation, D.R. and M.-E.H.C.; resources, D.R. and M.-E.H.C.; data curation, R.O.; writing-original draft preparation, D.R.; writing-review and editing, E.A. and R.O.; visualization, R.O.; supervision, E.A.; project administration, D.R.; funding acquisition, D.R. and E.A. All authors have read and agreed to the published version of the manuscript.

Funding: This research was funded by the "Programa de Apoyo a Proyectos de Investigación e Innovación Tecnológica (PAPIIT)" of the National Autonomous University of Mexico (UNAM), grant number IA302220 and The APC was funded by UNAM.

Acknowledgments: Authors thank Servicio Meteorologico Nacional for providing data. D.R. thanks the "Programa de Apoyo a Proyectos de Investigación e Innovación Tecnológica (PAPIIT)" of the UNAM, grant number IA302220. EA thanks to the following University of Costa Rica projects: 805-C0-610 (Fondo de Estímulo), EC-497 (Fondo de extensión FEES-CONARE), 805-B8-766 (Fondo de apoyo a Redes Temáticas), 805-C0-074 y 805-B9-454 (Fondo de Grupos).

Conflicts of Interest: The authors declare no conflict of interest. The funders had no role in the design of the study; in the collection, analyses, or interpretation of data; in the writing of the manuscript, or in the decision to publish the results.

\section{References}

1. CRED EM-DAT, The International Disaster Database. Available online: http://www.emdat.be/ (accessed on 10 April 2018).

2. Wilhite, D.A. Drought as a natural hazard: Concepts and definitions. In Drought: A Global Assessment; Routledge: Abingdon-on-Thames, UK, 2000; pp. 3-18.

3. Esparza, M. La sequía y la escasez de agua en México: Situación actual y perspectivas futuras. Secuencia 2014, 89, 193-219.

4. Graniel, E.; Vera, I.; González Hita, L. Dinámica de la interfase salina y calidad del agua en la Costa Nororiental de Yucatán. Ingeniería 2004, 8, 15-25.

5. Hayes, M.J. Drought Indices. In Van Nostrand's Scientific Encyclopedia; John Wiley \& Sons, Inc.: Hoboken, NJ, USA, 2005; ISBN 978-0-471-74398-9.

6. Keyantash, J.; Dracup, J.A. The quantification of drought: An evaluation of drought indices. Bull. Am. Meteorol. Soc. 2002, 83, 1167.

7. Palmer, W.C. Meteorological Drought; Research Paper No. 45; US Department of Commerce, Weather Bureau: Washington, DC, USA, 1965; Volume 30.

8. McKee, T.B.; Doesken, N.J.; Kleist, J. The relationship of drought frequency and duration to time scales. In Proceedings of the 8th Conference on Applied Climatology, American Meteorological Society, Anaheim, CA, USA, 17-22 January 1993; Volume 17, pp. 179-183.

9. Svoboda, M.; Hayes, M.; Wood, D. Standardized Precipitation Index User Guide; World Meteorological Organization: Geneva, Switzerland, 2012.

10. Dai, A.; Trenberth, K.E.; Karl, T.R. Global variations in droughts and wet spells: 1900-1995. Geophys. Res. Lett. 1998, 25, 3367-3370.

11. World Meteorological Organization; Global Water Partnership. Handbook of Drought Indicators and Indices; Integrated Drought Management Programme, Integrated Drought Management Tools and Guidelines Series 2; Svoboda, M., Fuchs, B.A., Eds.; World Meteorological Organization: Geneva, Switzerland, 2016; ISBN 978-92-63-11173-9.

12. Tsakiris, G.; Vangelis, H. Towards a drought watch system based on spatial SPI. Water Resour. Manag. 2004, 18, 1-12.

13. Guttman, N.B. Comparing the Palmer Drought Index and the Standardized Precipitation Index. JAWRA J. Am. Water Resour. Assoc. 1998, 34, 113-121.

14. Giddings, L.; Soto, M.; Rutherford, B.M.; Maarouf, A. Standardized Precipitation Index Zones for México. ATM 2009, 18, 33-56.

15. Hallack-Alegria, M.; Watkins, D.W. Annual and Warm Season Drought Intensity-Duration-Frequency Analysis for Sonora, Mexico. J. Clim. 2007, 20, 1897-1909.

16. Quesada-Hernández, L.E.; Calvo-Solano, O.D.; Hidalgo, H.G.; Pérez-Briceño, P.M.; Alfaro, E.J. Dynamical delimitation of the Central American Dry Corridor (CADC) using drought indices and aridity values. Prog. Phys. Geogr. Earth Environ. 2019, 43, 627-642. 
17. Livada, I.; Assimakopoulos, V.D. Spatial and temporal analysis of drought in Greece using the Standardized Precipitation Index (SPI). Theor. Appl. Climatol. 2007, 89, 143-153.

18. Climate Prediction Center Drought Indices: Standardized Precipitation Index. Available online: https: //www.cpc.ncep.noaa.gov/products/Drought/Monitoring/spi.shtml (accessed on 19 June 2019).

19. Gómez Díaz, J.D.; Monterroso Rivas, A.I.; Lechuga Gayosso, L.M. Frecuencia y severidad de la sequía en la Península de Yucatán como instrumento para el ordenamiento del territorio. In Clima, Sociedad, Riesgos y Ordenación del Territorio; Olcina Cantos, J., Rico Amorós, A.M., Moltó Mantero, E., Eds.; Servicio de Publicaciones de la UA: Alicante, Sevilla, 2016; pp. 525-533.

20. Servicio Meteorológico Nacional Monitor de Sequía en México. Available online: https://smn.cna.gob.mx/es/ climatologia/monitor-de-sequia/monitor-de-sequia-en-mexico (accessed on 19 June 2019).

21. Wang, H.; Gao, J.E.; Zhang, M.; Li, X.; Zhang, S.; Jia, L. Effects of rainfall intensity on groundwater recharge based on simulated rainfall experiments and a groundwater flow model. Catena 2015, 127, 80-91.

22. Amador, J.A. The Intra-Americas Sea Low-level Jet. Ann. N. Y. Acad. Sci. 2008, 1146, 153-188. [PubMed]

23. Magaña, V.; Amador, J.A.; Medina, S. The midsummer drought over Mexico and Central America. J. Clim. 1999, 12, 1577-1588.

24. Perdigón-Morales, J.; Romero-Centeno, R.; Pérez, P.O.; Barrett, B.S. The midsummer drought in Mexico: Perspectives on duration and intensity from the CHIRPS precipitation database: Midsummer Drought IN Mexico Through The Chirps Database. Int. J. Climatol. 2018, 38, 2174-2186.

25. Romero, D.; Torres-Irineo, E.; Kern, S.; Orellana, R.; Hernandez-Cerda, M.E. Determination of the soil moisture recession constant from satellite data: A case study of the Yucatan peninsula. Int. J. Remote Sens. 2017, 38, 5793-5813.

26. Magaña, V.O.; Vázquez, J. Interannual variability of Northern activity over the Americas. In Proceedings of the 24th Conference on Hurricanes and Tropical Meteorology, Lauderdale, FL, USA, 29 May-2 June 2000; Volume 29.

27. Orellana, L.R.; Espadas, C.; González, I.J.A. Aplicaciones de los diagramas ombrotérmicos de Gaussen modificados en la Península de Yucatán. Mex. Unid. Divers. Ter. 2002, 1, 60-68.

28. Vidal, R. Las Regiones Climáticas de México; Temas selectos de la Geografía de México; Instituto de Geografía UNAM: México DF, México, 2005.

29. Köppen, W. Versuch einer Klassifikation der Klimate, vorzugsweise nach ihren Beziehungen zur Pflanzenwelt. Geogr. Z. 1900, 6, 593-611, 657-679.

30. García, E. Modificaciones al Sistema de Clasificación Climática de Köppen, 5th ed.; Universidad Nacional Autónoma de México, Instituto de Geografía: CDMX, México, 2004; ISBN 970-32-1010-4.

31. Yihdego, Y.; Vaheddoost, B.; Al-Weshah, R.A. Drought indices and indicators revisited. Arab. J. Geosci. 2019, 12, 69.

32. García, E. CONABIO “Climas" (clasificación de Koppen, modificado por García) Escala 1:1000000; CONABIO: Mexcico City, Mexico, 1998.

33. Delgado Carranza, C. Zonificación agroecológica del estado de Yucatán con base en índices agroclimáticos y calidad agrícola del agua subterránea. Ph.D. Thesis, Centro de Investigación Científica de Yucatán, Merida, Mexico, 2010.

34. R Core Team. R: A Language and Environment for Statistical Computing; R Foundation for Statistical Computing: Vienna, Austria, 2020.

35. Goward, S.N.; Markham, B.; Dye, D.G.; Dulaney, W.; Yang, J. Normalized difference vegetation index measurements from the advanced very high resolution radiometer. Remote Sens. Environ. 1991, 35, $257-277$.

36. Granados-Ramírez, R.; Reyna-Trujillo, T.; Gómez-Rodríguez, G.; Soria-Ruiz, J. Analysis of NOAA-AVHRR-NDVI images for crops monitoring. Int. J. Remote Sens. 2004, 25, 1615-1627.

37. Silva, F.B.; Shimabukuro, Y.E.; Aragao, L.E.; Anderson, L.O.; Pereira, G.; Cardozo, F.; Arai, E. Large-scale heterogeneity of Amazonian phenology revealed from 26-year long AVHRR/NDVI time-series. Environ. Res. Lett. 2013, 8, 024011.

38. García, E.; Hernández, M.E.; Cardozo, N.D. Las gráficas ombrotérmicas y los regímenes pluviométricos en la República Mexicana. In Proceedings of the Memoria del IX Congreso Nacional de Geografía, Sociedad Mexicana de Geografía y Estadística, Guadalajara, Mexico, February 1983; pp. 140-149. 
39. Márdero, S.; Nickl, E.; Schmook, B.; Schneider, L.; Rogan, J.; Christman, Z.; Lawrence, D. Sequías en el sur de la península de Yucatán: Análisis de la variabilidad anual y estacional de la precipitación. Investig. Geográficas 2012, 19-33. [CrossRef]

40. Hall, F.R. Base-Flow Recessions-A Review. Water Resour. Res. 1968, 4, 973-983.

41. Mariño, M.A.; Luthin, J.N. Seepage and Groundwater; Elsevier: Amsterdam, The Netherlands, 1982; ISBN 978-0-08-087004-5.

42. Too, V.K.; Omuto, C.T.; Biamah, E.K.; Obiero, J.P. Review of Soil Water Retention Characteristic (SWRC) Models between Saturation and Oven Dryness. Open J. Mod. Hydrol. 2014, 4, 173-182.

43. Anderson, M.G.; Burt, T.P. Interpretation of recession flow. J. Hydrol. 1980, 46, 89-101.

44. Blume, T.; Zehe, E.; Bronstert, A. Rainfall-runoff response, event-based runoff coefficients and hydrograph separation. Hydrol. Sci. J. 2007, 52, 843-862.

45. Chevalier, P. L'indice des précipitations antérieures. Cah. ORSTOM Hydrol. 1983, 20, 179-189.

46. Kohler, M.A.; Linsley, R.K. Predicting the Runoff from Storm Rainfall; National Oceanic and Atmospheric Administration Weather Bureau Research Papers; US Dept. of Commerce: Washington, DC, USA, 1951; p. 10.

47. Folger, P.; Cody, B.A.; Carter, N.T. Drought in the United States: Causes and Issues for Congress; Congressional Research Service, Library of Congress: Washington, DC, USA, 2012.

48. Wilson, K.B.; Hanson, P.J.; Mulholland, P.J.; Baldocchi, D.D.; Wullschleger, S.D. A comparison of methods for determining forest evapotranspiration and its components: Sap-flow, soil water budget, eddy covariance and catchment water balance. Agric. For. Meteorol. 2001, 106, 153-168.

49. Milly, P.C.D. Climate, soil water storage, and the average annual water balance. Water Resour. Res. 1994, 30, 2143-2156.

50. Crimmins, S.M.; Dobrowski, S.Z.; Greenberg, J.A.; Abatzoglou, J.T.; Mynsberge, A.R. Changes in Climatic Water Balance Drive Downhill Shifts in Plant Species' Optimum Elevations. Science 2011, 331, 324-327.

51. Murtaugh, P.A. In defense of P values. Ecology 2014, 95, 611-617.

52. Tucker, C.; Vanpraet, C.; Boerwinkel, E.; Gaston, A. Satellite remote sensing of total dry matter production in the Senegalese Sahel. Remote Sens. Environ. 1983, 13, 461-474.

53. Tucker, C.J.; Sellers, P.J. Satellite remote sensing of primary production. Int. J. Remote Sens. 1986, 7, 1395-1416.

54. Peters, A.J.; Walter-Shea, E.A.; Ji, L.; Viña, A.; Hayes, M.; Svoboda, M.D. Drought monitoring with NDVI-based Standardized Vegetation Index. Photogramm. Eng. Remote Sens. 2002, 68, 71-75.

55. Tucker, C.J.; Dregne, H.E.; Newcomb, W.W. Expansion and Contraction of the Sahara Desert from 1980 to 1990. Science 1991, 253, 299-300.

56. Gómez Rojas, J.C. Atlas Agroclimático de la República Mexicana; Universidad Nacional Autónoma de México: México DF, México, 2013; ISBN 978-607-03-4276-2.

57. Estrada-Medina, H.; Cobos-Gasca, V.; Acosta-Rodríguez, J.L.; Fierro, S.P.; Castilla-Martínez, M.; Castillo-Carrillo, C.; Franco-Brito, S.; López-Castillo, D.; López-Díaz, M.; Luna-Flores, W.; et al. La sequía de la península de Yucatán. Tecno. Cien. Agua 2016, 7, 151-165.

58. CENAPRED Características e Impacto Socioeconómico de los Principales Desastres Ocurridos en la República Mexicana en el año 2009; Centro Nacional de Prevención de Desastres: México DF, México, 2010.

59. SAGARPA Programa de Atención a Contingencias Climatológicas (PAAC). Evaluación Externa de Resultados; Universidad Autónoma de Chapingo, Secretaría de Agricultura, Ganadería, Desarrollo Rural, Pesca y Alimentación: México DF, México, 2010.

60. Wood, S.N. Thin plate regression splines. J. R. Stat. Soc. Ser. B (Stat. Methodol.) 2003, 65, 95-114.

61. Florescano, E. Una historia olvidada: La sequía en México. Nexos 1980, 32, 9-18.

62. Domínguez, J. Revisión histórica de las sequías en México: De la explicación divina a la incorporación de la ciencia. Tecnol. Cienc Agua 2016, 7, 77-93.

63. García, E.; Hernandez, M.E. Anomalías de la precipitación en la República Mexicana de 1921 a 1980. Rev. Geogr. 1988, 2, 1-24.

64. Alfaro, E.J. Eventos cálidos y fríos en el Atlántico Tropical Norte. Atmósfera 2000, 13, 109-119.

65. Maldonado, T.; Alfaro, E.; Rutgersson, A.; Amador, J.A. The early rainy season in Central America: The role of the tropical North Atlantic SSTs: Early Rainy Season in Central America and The TNA SST. Int. J. Climatol. 2017, 37, 3731-3742.

66. Taylor, M.A. Influence of the tropical Atlantic versus the tropical Pacific on Caribbean rainfall. J. Geophys. Res. 2002, 107, 10-11. 
67. Martinez, C.; Goddard, L.; Kushnir, Y.; Ting, M. Seasonal climatology and dynamical mechanisms of rainfall in the Caribbean. Clim. Dyn. 2019, 53, 825-846.

68. Martinez, C.; Kushnir, Y.; Goddard, L.; Ting, M. Interannual variability of the early and late-rainy seasons in the Caribbean. Clim. Dyn. 2020, 55, 1563-1583.

69. Orellana, R.; Espadas, C.; Conde, C.; Gay, C. Atlas de Escenarios de Cambio Climático en la Península de Yucatán; Centro de Investigación Científica de Yucatán, A.C.: Mérida, México, 2009.

70. Le, M.H.; Perez, G.C.; Solomatine, D.; Nguyen, L.B. Meteorological Drought Forecasting Based on Climate Signals Using Artificial Neural Network-A Case Study in Khanhhoa Province Vietnam. Procedia Eng. 2016, 154, 1169-1175.

71. Vicente-Serrano, S.M.; Beguería, S.; López-Moreno, J.I. A multiscalar drought index sensitive to global warming: The standardized precipitation evapotranspiration index. J. Clim. 2010, 23, 1696-1718.

72. Park Williams, A.; Allen, C.D.; Macalady, A.K.; Griffin, D.; Woodhouse, C.A.; Meko, D.M.; Swetnam, T.W.; Rauscher, S.A.; Seager, R.; Grissino-Mayer, H.D.; et al. Temperature as a potent driver of regional forest drought stress and tree mortality. Nat. Clim. Chang. 2013, 3, 292-297.

Publisher's Note: MDPI stays neutral with regard to jurisdictional claims in published maps and institutional affiliations.

(C) 2020 by the authors. Licensee MDPI, Basel, Switzerland. This article is an open access article distributed under the terms and conditions of the Creative Commons Attribution (CC BY) license (http://creativecommons.org/licenses/by/4.0/). 